\title{
PENGARUH METODE PEMBELAJARAN DAN KEMAMPUAN AWAL TERHADAP HASIL BELAJAR SISWA PADA MATA PELAJARAN INSTALASI PENERANGAN LISTRIK KELAS XI SMKN 34 JAKARTA
}

\author{
${ }^{1}$ Eka Nur Wulandari, ${ }^{2}$ Soeprijanto, ${ }^{3}$ Massus Subekti \\ 1,2,3 Pendidikan Teknik Elektro, Fakultas Teknik, Universitas Negeri Jakarta \\ 1,2,3 Email: ekanurw252@gmail.com; soeprijanto@unj.ac.id ; masus@unj.ac.id
}

\begin{abstract}
The type of research used is quasy experimental, using mind mapping methods and using inquiry methods. The process of data collection is done with report cards and pre-tests to determine the group of students who have high and low initial abilities. In determining the group, it is necessary to test the correlation coefficient between the report value and the pre-test results, the test results obtained a high correlation with a positive relationship so that in determining the initial ability group using the pre-test results because in determining the results using the pre-test questions which was developed into a post-test question. strengthen the results of research in both classes. The collected data will be processed by two-way ANAVA test and follow-up test namely tuckey test after the data meets the normal and homogeneous requirements. The results of the first hypothesis study show that Fcount> Ftable is 80.94> 69.33 at a significant level of 5\%. likewise the follow-up test with the tuckey test shows that the value of $Q$ count $=11.06$ which is greater than Qtable $(0.05 ; 2 / 32)=2.88$. The second hypothesis shows that Qcount is 9.89> Qtable which is 4.05 at the real level $\alpha=0.05$. The third hypothesis shows that $Q$ count is 5.80> Qtable which is 4.05 at the real level $\alpha=0.05$. The fourth hypothesis of calculation of ANAVA obtained the results of Fcount for interaction factors which is 4.16 greater than Ftable which is 3.89 at the real level $\alpha=0.05$. So that the results of Fcount $>$ Ftable, and the tuckey test show that the value of Qcount $=11.95$ which is greater than Qtable $(0.05 ; 4 / 16)=4.05$. And the fifth hypothesis obtained the results of Fcount for interaction factors which is 4.16 greater than Ftable which is 3.89 at the real level $\alpha=0.05$. So that the results of Fcount> Ftable, then the null hypothesis (Ho) is rejected and $\mathrm{HI}$ is accepted. From the proof of the hypothesis shows that there is the influence of mind mapping learning methods with differences in the initial abilities of the learning outcomes of class XI electrical lighting installations at SMKN 34 Jakarta.
\end{abstract}

Keywords: learning methods, initial abilities, learning outcomes, mind mapping methods, the influence of learning media.

\begin{abstract}
Abstrak
Pada penelitian yang digunakan adalah quasy eksperimental, menggunakan metode mind mapping dan menggunakan metode inkuiri. Proses pengumpulan data dilakukan dengan nilai rapor dan pre-test guna menentukan kelompok siswa yang memiliki kemampuan awal tinggi dan rendah. Dalam penentuan kelompok tersebut maka perlu dilakukan uji koefisien korelasi antara nilai rapor dan hasil pre-test, dalam uji tersebut diperoleh hasil korelasi yang tinggi dengan hubungan positif sehingga dalam penentuan kelompok kemampuan awal menggunakan hasil pre-test karena dalam penentuan hasil ini menggunakan soal pre- test yang dikembangkan menjadi soal post-test. memperkuat hasil penelitian pada kedua kelas. Data yang telah terkumpul akan diolah dengan uji ANAVA dua jalur dan uji lanjutan yaitu uji tuckey setelah data memenuhi persyaratan normal dan homogen. Hasil penelitian hipotesis pertama menunjukan bahwa $F_{h i t u n g}>F_{\text {tabel }}$ yakni 80,94> 69,33 pada taraf signifikan 5\%. demikian pula uji lanjutan dengan uji tuckey menunjukan bahwa nilai $Q_{\text {hitung }}=11,06$ yang bernilai lebih besar dari $\mathrm{Q}_{\text {tabel }(0,05 ; 2 / 32)}=2,88$. Hipotesis kedua menunjukan $\mathrm{Q}_{\text {hitung }}$ yaitu 9,89> $\mathrm{Q}_{\text {tabel }}$ yaitu 4,05 pada taraf nyata $\alpha=0,05$. Hipotesis ketiga menunjukan Qhitung yaitu 5,80 > Qtabel yaitu 4,05 pada taraf nyata $\alpha=0,05$. Hipotesis ke empat perhitungan ANAVA diperoleh hasil $F_{\text {hitung }}$ untuk faktor interaksi yaitu 4,16 lebih besar daripada $F_{\text {tabel }}$ yaitu 3,89 pada taraf nyata $\alpha=0,05$. Sehingga diperoleh hasil $F_{\text {hitung }}>F_{\text {tabel, }}$ serta uji tuckey menunjukan bahwa nilai $Q_{\text {hitung }}=11,95$ yang bernilai lebih besar dari $Q_{\text {tabel }(0,05 ; 4 / 16)}=4,05$. Dan hipotesis kelima diperoleh hasil $F_{\text {hitung }}$ untuk faktor interaksi yaitu 4,16 lebih besar daripada $F_{\text {tabel }}$ yaitu 3,89 pada taraf nyata $\alpha=0,05$. Sehingga diperoleh hasil $F_{\text {hitung }}>F_{\text {tabel, }}$ maka hipotesis nol (Ho) di tolak dan $\mathrm{H}_{1}$ diterima. Dari pembuktian hipotesis menunjukan bahwa terdapat pengaruh metode pembelajaran mind mapping dengan perbedaan kemampuan awal terhadap hasil belajar instalasi penerangan listrik kelas XI pada SMKN 34 Jakarta.
\end{abstract}

Kata kunci : metode pembelajaran, kemampuan awal, hasil belajar, metode mind mapping, pengaruh media pembelajaran. 


\section{PENDAHULUAN}

Sekolah Menengah Kejuruan (SMK) merupakan pendidikan formal pada tingkat menengah yang membekali peserta didiknya dengan keahlian dan ketrampilan di bidang tertentu dalam menghadapi dunia kerja. SMK mempunyai peran strategis dalam mendukung secara langsung pembangunan nasional, khususnya untuk mempersiapkan tenaga kerja lebih terampil dan terdidik yang dibutuhkan oleh dunia industry. Sejalan dengan tujuan tersebut, maka siswa SMK dibekali pengetahuan dan ketrampilan sesuai jurusan masing-masing. Misal jurusan mesin,otomotif, produktif listrik, DLL. Rendahnya aktivitas dan hasil belajar siswa pada mata pelajaran produktif listrik disebabkan oleh beberapa faktor diantaranya: (1) cara mangajar guru masih menggunakan metode pembelajaran yang masih bersifat konvensional seperti guru lebih banyak menggunakan metode ceramah dan penugasan sehingga membuat siswa merasa bosan dan kurang menarik.(2) pembelajaran masih berpusat pada guru (teacher centered) sehingga siswa cenderung ribut, mengganggu teman dan mengobrol yang mangakibatkan pembelajaran tidak kondusif. (3) kurangnya minat dan perhatian siswa terhadap materi yang disampaikan.

Metode pembelajaran terus mengalami perkembangan, sejalan dengan kemajuan teknologi dan informasi. Guru sebagai pendidik yang membelajarkan, dituntut untuk terus mengikuti perkembangan konsep- konsep baru dalam pembelajaran. Proses pembelajaran selama ini sebagian besar dilakukan melalui penyampaian informasi yang berpusat pada kegiatan mendengarkan dan menghafalkan, bukan memberikan interprestasi maupun makna terhadap apa yang dipelajari dalam upaya untuk membangun pengetahuan sendiri. Sementara itu siswa juga akan dipaksa untuk menerima sedemikian banyak pelajaran tanpa memilki waktu yang cukup untuk mendalaminya (dalam jurnal Aziz, 2012). Oleh karena itu perlu adanya pemilihan metode pembelajaran yang cocok untuk menyampaikan materi pelajaran yang diberikan agar mudah untuk diterima siswa dan tercapainya tujuan belajar, yaitu siswa mampu meningkatkan hasil belajar, terciptanya aktivitas belajar yang tercontrol dan kondusif, tercapainya target belajar sesuai dengan silabus mata pelajaran yang telah tersedia dan siswa mampu mengimplikasikan pembelajaran yang didapatkan di sekolah untuk di implikasikan dilingkungan luar sekolah. Salah satu metode yang dapat di gunakan adalah dengan metode pembelajaran mind mapping.

Hingga saat ini mind mapping semakin banyak di implikasikan dalam berbagai bidang, khususnya dalam bidang pendidikan. Mind mapping juga mengalami perkembangan dalam segi tampilan yang lebih menarik terbukti dengan banyaknya aplikasi yang dipergunakan khusus untuk membuat mind mapping. Mind mapping sendiri adalah suatu visualisasi pengetahuan secara grafis untuk mengoptimalkan eksplorasi seluruh area kemampuan otak (Swadarma, 2013: 2). Melalui metode pembelajaran mind mapping ini di harapkan dapat mengembangkan potensi-potensi yang dimiliki siswa secara optimal, menggunakan otak kiri dan otak kanan sehingga siswa dapat lebih menyerap materi yang diajarkan. Dalam mind mapping, materi pelajaran tidak bagitu saja diterapkan kepada peserta didik akan tetapi siswa diarahkan untuk menemukan sendiri konsep yang dimaksud melalui pengalaman belajar peserta didik dengan cara menganalisis dan mengkonstruksikan hingga terbentuk pemahaman baru dalam diri mereka. Pembelajaran ini bertujuan untuk meningkatkan kemampuan berfikir namun biasa diterapkan dalam mata pelajaran umum (IPS, Biologi dan Matematika).

Tidak hanya metode pembelajaran yang mempengaruhi hasil belajar siswa, melainkan terdapat dugaan faktor kemampuan awal siswa terhadap pelajaran yang diberikan juga dapat mempengaruhi hasil belajar siswa. Menurut Dick and Lou (dalam jurnal Hanun, 2008), kemampuan awal merupakan pengetahuan atau keterampilan yang telah dimiliki siswa sebelum ia mengikuti mata pelajaran yang akan diberikan. Sejalan dengan Herawati dkk, 2013 (dalam jurnal Anggraini dkk, 2013 ), kemampuan awal juga dipandang sebagai keterampilan yang relevan yang dimiliki pada saat akan mulai mengikuti suatu pembelajaran sehingga dapat dikatakan bahwa kemampuan awal merupakan prasyarat yang harus dikuasai siswa sebelum mengikuti pembelajaran. Dari pengertian diatas dapat diambil kesimpulan bahwa kemampuan awal merupakan salah satu faktor yang harus diperhatikan dalam proses belajar mengajar, 
karena dari kemampuan awal siswa yang dimilki pendidik dapat mengindetifikasi sejauh mana siswa mampu mengikuti pembelajaran dengan baik.

Pada pembelajaran produktif listrik yang berfokus pada mata pelajaran Instalasi Penerangan Listrik dalam materi tata letak komponen listrik dan PUIL yang dipelajari pada kelas XI. Berfokus pada mata pelajaran Instalasi Penerangan Listrik karena mata pelajaran tersebut merupakan mata pelajaran dasar yang menjadi titik awal siswa kelas XI mengenal tentang ilmu instalasi listrik rumah sederhana sehingga di butuhkan metode pembelajaran yang mampu mendorong siswa untuk dapat memahami materi lebih maksimal sehingga untuk pemahaman mata pelajaran listrik yang lain akan dirasa lebih mudah.

Dalam pemilihan materi di pilih materi PUIL dan tata letak komponen instalasi penerangan listrik pada bangunan sederhana karena pada materi tersebut terdapat tata letak komponen listrik yang digunakan dalam instalasi penerangan listrik dengan berlandaskan PUIL, sehingga dapat memudahkan pemasangan dengan memperhatikan tata letak komponen agar terpasang instalasi listrik yang baik dan aman. untuk itu siswa diharapkan mampu memahami dan mengimplementasikan materi tersebut melalui penggunaan mind mapping ini dengan mudah. Mengingat pencapaian tujuan pembelajaran ini, setiap guru dituntut untuk benar-benar memahami metode pembelajaran yang akan di terapkannya dengan tetap memperhatikan kemampuan awal yang dimiliki siswa. Sehubungan dengan hal tersebut pendidik perlu memikirkan metode atau pendekatan yang akan di gunakan. Pemilihan metode pembelajaran yang tepat, yaitu dengan situasi dan kondisi yang di hadapi akan berdampak pada tingkat penguasaan atau prestasi belajar peserta didiknya.

\section{METODOLOGI PENELITIAN}

Penelitian ini menggunakan desain treatment by level $2 \times 2$,pemilihan desain ini disesuaikan dengan data yang diharapkan dari dua variable bebas, yaitu perbedaan hasil belajar intalasi penerangan listrik akibat pengaruh penerapan metode pembelajaran mind mapping dan metode pemebelajaran inkuiri pada siswa dengan kemampuan awal tinggi dan kemampuan awal rendah.

Tabel 1: Matrik Desain Treatment by level $2 \times 2$

\begin{tabular}{ccc}
\hline \multirow{2}{*}{ Kemampuan Awal (B) } & \multicolumn{2}{c}{ Metode Pembelajaran (A) } \\
\cline { 2 - 3 } & Mind Mapping & Inkuiri \\
& $\left(\mathrm{A}_{1}\right)$ & $\left(\mathrm{A}_{2}\right)$ \\
\hline Tinggi $\left(\mathrm{B}_{1}\right)$ & $\mathrm{A}_{1} \mathrm{~B}_{1}$ & $\mathrm{~A}_{2} \mathrm{~B}_{1}$ \\
Rendah $\left(\mathrm{B}_{2}\right)$ & $\mathrm{A}_{1} \mathrm{~B}_{2}$ & $\mathrm{~A}_{2} \mathrm{~B}_{2}$ \\
\hline
\end{tabular}

Keterangan:

A1 = Kelompok siswa yang belajar dengan metode pembelajaran mind mapping

A2 = Kelompok siswa yang belajar dengan metode pembelajaran inkuiri

B1 = Kelompok siswa yang memiliki kemampuan awal tinggi

B2 = Kelompok siswa yang memiliki kemampuan awal rendah

A1B1 = Hasil belajar IPL pada siswa yang memiliki kemampuan awal tinggi dengan menggunakan metode pembelajaran mind mapping

A1B2 = Hasil belajar IPL pada siswa yang memiliki kemampuan awal rendah dengan menggunakan metode pembelajaran mind mapping

A2B1 = Hasil belajar IPL pada siswa dengan kemampuan awal tinggi dengan menggunakan metode pembelajaran inkuiri

A2B2 = Hasil belajar IPL pada siswa dengan kemampuan awal rendah dengan menggunakan metode pembelajaran inkuiri

Teknik pengumpulan data dalam penelitian diperoleh dari instrumen kemampuan awal berupa nilai rapor kelas $\mathrm{X}$ dan soal pilihan ganda (pre-test) sebanyak 35 soal yang berkaitan dengan materi pada kompetensi dasar 3.1 dan 3.2 yang akan digunakan pada penelitian. Dari kedua instrumen akan di uji menggunakan uji koefisien korelasi guna mmeperoleh hasil korelasi tinggi sehingga dari kedua dapat di pilih salah satu yang akan digunakan sebagai penentu kemampuan awal.

Teknik pengumpulan data dalam penelitian diperoleh dari instrumen hasil belajar instalasi penerangan listrik berupa 
pilihan ganda sebanyak 35 soal yang berkaitan dengan materi pada kompetensi dasar 3.1 dan 3.2 yang akan digunakan pada penelitian. Dengan memberikan instrumen kemampuan awal yang dilakukan, diharapkan dapat diperoleh data kuantitatif dari hipotesis yang diajukan.

Analisis data menggunakan statistik pada Ms. Excel yang dipakai untuk 1) Analisis deskriptif (mendeskripsikan data mentah). 2) Uji persyaratan analisis data (uji normalitas dan homogenitas), dan 3) Uji hipotesis (two way Anova).

\section{Hasil Penelitian dan Pembahasan Koefisien Korelasi}

Koefisien korelasi merupakam angka yang menunjukan tinggi atau rendahnya hubungan antara dua variabel atau lebih menurut Budi Susetyo (2009:121). Dari perhitungan koefisien Dalam penelitian ini terdapat dua instrumen yang dipergunakan untuk menentukan kelompok tingkat kemampuan awal siswa. Dua instrumen tersebut yaitu nilai rapor dan nilai pre-test yang dilakukan sebelum pemberian materi. Dari kedua intrumen akan diambil salah satu untuk menentukan kelompok kemampuan awal tinggi dan rendah. Untuk dapat memilih salah satu dari instrumen tersebut maka perlu diadakannya uji korelasi antara kedua instrumen yang menghasilkan korelasi yang sempurna atau tinggi diantara kedua instrumen. Koefisien korelasi antara nilai rapor (X) dan hasil pre-test (Y) untuk kelas kontrol (XI- L1). Dari perhitungan yang dilakukan diperoleh hasil pada korelasi yang kuat positif dari kedua kelas sehingga pada penelitian ini instrument kemampuan awal menggunakan pre-test karena soal pre-test yang akan di gunakan dan dikembangkan kembali untuksoal post-te

\section{Pengujian Prasyarat Analisis}

Pengujian Normalitas

Pengujian normalitas dilakukan dengan menggunakan uji Liliefors pada taraf signifikan $\alpha=0,05$ dengan kriteria apabila nilai Lhitung (L0) lebih kecil dari Ltabel (Lt) maka data berdistribusi normal.
Tabel 2. Rangkuman Hasil Uji Normalitas

\begin{tabular}{ccccc}
\hline KELOMPOK & SAMPEL & $\mathbf{L}_{\text {bitug }}$ & $\mathbf{L}_{\text {tabel }}$ & KETERANGAN \\
\hline A1 & 32 & 0,1560 & 0,160 & Normal \\
A2 & 32 & 0,0312 & 0,160 & Normal \\
B1 & 32 & 0,1151 & 0,160 & Normal \\
B2 & 32 & 0,1036 & 0,160 & Normal \\
A1B1 & 16 & 0,1444 & 0,213 & Normal \\
A2B1 & 16 & 0,1653 & 0,213 & Normal \\
A1B2 & 16 & 0,0522 & 0,213 & Normal \\
A2B2 & 16 & 0,1239 & 0,213 & Normal
\end{tabular}

Pengujian Homogenitas

Uji homogenitas dilakukan terhadap data kombinasi perlakuan antara metode pembelajaran dan kemampuan awal siswa $\left(A_{1} B_{1}, A_{1} B_{2}, A_{2} B_{1}\right.$, dan $\left.A_{2} B_{2}\right)$. Pengujian homogenitas dilakukan dengan menggunakan uji barlett pada taraf signifikan $\alpha=0,05$.

Tabel 3. Rangkuman Hasil Uji Homogenitas

\begin{tabular}{lccccc}
\hline Kelompers & $\begin{array}{c}\text { Varians } \\
\left(\mathrm{N}_{i}^{2}\right)\end{array}$ & $\begin{array}{c}\text { Varian } \\
\text { Gabungan } \\
\left(\mathrm{S}^{2}\right)\end{array}$ & $\chi_{\text {bituax }}^{2}$ & $\chi_{\text {tabal }}^{2}$ & Kesimpulan \\
\hline A1B1 & 17,92 & & & & \\
A2B1 & 29,48 & 35,23 & 4,55 & 7,81 & Homogen \\
A1B2 & 40,96 & & & & \\
A2B2 & 52,55 & & & & \\
\hline
\end{tabular}

\section{Pengujian Hipotesis dan Pembahasan}

Pengujian hipotesis dapat dilakukan setelah persyaratan untuk pengujian analisis terpenuhi, yaitu uji normalitas dan homogenitas. Pengujian hipotesis ini dilakukan untuk menguji semua efek utama dan efek interaksi terhadap hasil belajar dengan menggunakan analisis varians (ANAVA) dua jalur dan di lanjut uji Tuckey karena terdapat interaksi di dalam pengujian.

Tabel 4. Rangkuman Hasil Perhitungan

Analisis

\begin{tabular}{|c|c|c|c|c|c|}
\hline sumber variasi & $\begin{array}{c}\text { Jumlah } \\
\text { Kuadrat } \\
\text { (JK) }\end{array}$ & $\begin{array}{c}\text { Dexajat } \\
\text { Bebas } \\
\text { (df) }\end{array}$ & $\begin{array}{c}\text { Jumlah } \\
\text { Rata- } \\
\text { Rata } \\
\text { Kuadrat } \\
\text { (RK) } \\
\end{array}$ & F hitung & $\underset{\text { tabel }}{\mathbf{F}}$ \\
\hline Antar Kolom(Metode) & $2,158.76$ & 1 & $2,158.76$ & $61.28^{* *}$ & \\
\hline $\begin{array}{l}\text { Antar Baris (Kemampuan } \\
\text { ayxal) }\end{array}$ & 591.10 & 1 & 591.10 & $16.78^{* *}$ & $\begin{array}{l}3.82 \\
(5 \%)\end{array}$ \\
\hline Kolom dan Baris (Interaksi) & 146.71 & 1 & 146.71 & $4.16^{* *}$ & \\
\hline Dalam Kelompok & $2,113.53$ & 60 & 35.23 & & \\
\hline Jumlah Keseluruhan (TR) & $5,010.10$ & 63 & & & \\
\hline
\end{tabular}

Hipotesis 1

Terdapat perbedaan yang signifikan hasil belajar antara siswa yang mendapat pembelajaran dengan metode pembelajaran mind mapping $\left(\mathrm{A}_{1}\right)$ dan metode inkuiri $\left(\mathrm{A}_{2}\right)$. 
Hipotesis ini secara statistik dirumuskan sebagai berikut:

$$
\begin{aligned}
& \mathrm{H} 0: \mu \mathrm{A} 1=\mu \mathrm{A} 2 \\
& \mathrm{H} 1: \mu \mathrm{A} 1>\mu \mathrm{A} 2
\end{aligned}
$$

Tabel 5. Rangkuman Uji Tuckey Hasil Belajar IPL Siswa Antara yang Belajar Menggunakan Metode Pembelajaran Mind Mapping dan Inkuiri

\begin{tabular}{cccc}
\hline $\begin{array}{c}\text { Kelompokyang } \\
\text { Dibandingkan }\end{array}$ & $\mathbf{Q}_{\text {hitugg }}$ & $\mathbf{Q}_{\text {tabel }}$ & Kesimpulan \\
\cline { 3 - 3 } & & $\boldsymbol{\alpha}=\mathbf{0 , 0 5}$ & \\
\hline A1 - A2 & $11,06^{* *}$ & 2,88 & Tolak Ho \\
\hline
\end{tabular}

Berdasarkan perhitungan ANAVA dua jalur diperoleh Fhitung untuk metode pembelajaran sebesar 61,28, sedangkan Ftabel sebesar 3,89 pada taraf signifikan $\alpha=0,05$. Sehingga diperoleh hasil Fhitung $>$ Ftabel, maka hipotesis nol (Ho) di tolak dan H1 diterima. Hasil tersebut menunjukan bahwa terdapat perbedaan hasil belajar IPL antara siswa yang mendapatkan pembelajaran dengan metode mind mapping dan inkuiri. Demikian pula uji lanjutan dengan uji tuckey menunjukan bahwa nilai Qhitung $=11,06$ yang bernilai lebih besar dari Qtabel $(0,05 ; 2 / 32)$ $=2,88$. Dengan demikian dapat disimpulkan bahwa terdapat perbedaan hasil belajar IPL yang signifikan antara siswa yang menggunakan metode mind mapping dan inkuiri. Dengan perkataan lain bahwa metode pembelajaran mind mapping ( rata-rata $=80,94$ ) lebih baik dari pada metode pembelajaran inkuiri (rata- rata $=69,33$ ). Ini berarti hipotesis penelitian yang menyatakan bahwa secara keseluruhan metode pembelajaran mind mapping lebih baik dibanding dengan metode inkuiri.

\section{Hipotesis 2}

Terdapat perbedaan yang signifikan dari hasil belajar antara siswa yang memiliki kemampuan awal tinggi dengan metode mind mapping $\left(\mathrm{A}_{1} \mathrm{~B}_{1}\right)$ dan siswa yang memiliki kemampuan awal tinggi dengan metode inkuiri $\left(\mathrm{A}_{2} \mathrm{~B}_{1}\right)$ Hipotesis ini secara statistik dirumuskan sebagai berikut: $\mathrm{H} 0: \mu \mathrm{A} 1 \mathrm{~B} 1 \leq \mu \mathrm{A} 2 \mathrm{~B} 1$

$\mathrm{H} 1: \mu \mathrm{A} 1 \mathrm{~B} 1>\mu$

A2B1
Tabel 6. Rangkuman Uji Tuckey Hasil

Belajar IPL Siswa yang Memiliki

Kemampuan Tinggi yang Belajar

Menggunakan Metode Pembelajaran Mind

Mapping dan Inkuiri

\begin{tabular}{lccc}
\hline Kelompok yang & Qhitung $_{\text {Dibandingkan }}$ & Qtakel $^{\text {Kesimpulan }}$ \\
\cline { 3 - 3 } & & $\boldsymbol{\alpha}=\mathbf{0 , 0 5}$ & \\
\hline A1B1 -- A2B1 & $9,89^{* *}$ & 4,05 & Tolak Ho \\
\hline
\end{tabular}

Nilai rerata hasil belajar IPL siswa SMK kelas XI Listrik-2 yang memiliki kemampuan awal tinggi diberikan metode pembelajaran mind mapping adalah 85,49. Sedangkan nilai rerata hasil belajar IPL siswa SMK kelas XI Listrik-1 yang memiliki kemampuan awal tinggi diberikan metode pembelajaran inkuiri adalah 70,85 . Kedua nilai rerata ini dibandingkan dengan menggunakan uji tuckey dengan perhitungan yang menunjukan bahwa Qhitung yaitu 9,89> Qtabel yaitu 4,05 pada taraf nyata $\alpha=0,05$. Dengan demikian maka dapat disimpulkan bahwa Ho ditolak dan $\mathrm{H} 1$ diterima yang berarti bahwa untuk siswa yang mempunyai kemampuan awal tinggi, terdapat perbedaan hasil belajar IPL yang signifikan antara siswa yang menggunakan metode mind mapping dan inkuiri.

Ini berarti hipotesis penelitian yang menyatakan bahwa siswa dengan kemampuan awal tinggi saat diberikan metode pembelajaran mind mapping memperoleh hasil belajar yang lebih baik dibanding dengan siswa yang memiliki kemampuan awal tinggi yang diberikan metode inkuiri.

\section{Hipotesis 3}

Terdapat perbedaan yang signifikan dari hasil belajar antara siswa yang memiliki kemampuan awal rendah dengan metode mind mapping $\left(\mathrm{A}_{1} \mathrm{~B}_{2}\right)$ dan siswa yang memiliki kemampuan awal rendah dengan metode inkuiri $\left(\mathrm{A}_{2} \mathrm{~B}_{2}\right)$.

Hipotesis ini secara statistik dirumuskan sebagai berikut:

$$
\begin{aligned}
& \mathrm{H} 0: \mu \mathrm{A} 1 \mathrm{~B} 2 \leq \mu \mathrm{A} 2 \mathrm{~B} 2 \\
& \mathrm{H} 1: \mu \mathrm{A} 1 \mathrm{~B} 2>\mu \mathrm{A} 2 \mathrm{~B} 2
\end{aligned}
$$


Tabel 7. Rangkuman Uji Tuckey Hasil

Belajar IPL Siswa yang Memiliki

Kemampuan Rendah yang Belajar

Menggunakan Metode Pembelajaran Mind Mapping dan Inkuiri

\begin{tabular}{lccc}
\hline \multirow{2}{*}{$\begin{array}{c}\text { Kelompok yang } \\
\text { Dibandingkan }\end{array}$} & Q $_{\text {hitung }}$ & Q tabel & \\
\cline { 3 - 3 } & & $\boldsymbol{\alpha}=\mathbf{0 , 0 5}$ & Kesimpulan \\
\hline A1B2 - A2B2 & $5,80^{* *}$ & 4,05 & Tolak Ho \\
\hline
\end{tabular}

Nilai rerata hasil belajar IPL siswa SMK kelas XI Listrik-2 yang memiliki kemampuan awal rendah yang diberikan metode pembelajaran mind mapping adalah 76,39. Sedangkan nilai rerata hasil belajar IPL siswa SMK kelas XI Listrik-1 yang memiliki kemampuan awal rendah yang diberikan metode pembelajaran inkuiri adalah 67,80 . Kedua nilai rerata ini dibandingkan dengan menggunakan uji tuckey dengan perhitungan yang menunjukan bahwa Qhitung yaitu 5,80 > Qtabel yaitu 4,05 pada taraf nyata $\alpha=0,05$. Dengan demikian maka dapat disimpulkan bahwa Ho ditolak dan H1 diterima yang berarti bahwa untuk siswa yang mempunyai kemampuan awal rendah, terdapat perbedaan hasil belajar IPL yang signifikan antara siswa yang menggunakan metode mind mapping dan inkuiri.

Ini berarti hipotesis penelitian yang menyatakan bahwa siswa dengan kemampuan awal rendah saat diberikan metode pembelajaran mind mapping memperoleh hasil belajar yang lebih baik dibanding dengan siswa yang memiliki kemampuan awal rendah yang diberikan metode inkuiri.

\section{Hipotesis 4}

Terdapat pengaruh interaksi antara hasil belajar siswa yang memiliki kemampuan awal tinggi dengan menggunakan metode mind mapping (A1B1) dan kemampuan awal rendah dengan menggunakan metode inkuiri (A2B2). Hipotesis secara statistik dapat dirumuskan sebagai berikut:

$$
\begin{aligned}
& \mathrm{H} 0: \text { Int. A1B1 = Int. A2B2 } \\
& \mathrm{H} 1: \text { Int. A1B1 } \neq \text { Int. A2B2 }
\end{aligned}
$$

Tabel 8. Rangkuman Uji Tuckey Pengaruh Interaksi Antara Hasil Belajar Siswa Yang MemilikiKemampuan Awal Tinggi Dengan Menggunakan Metode Mind Mapping Dan

Kemampuan Awal Rendah Dengan Menggunakan Metode Inkuiri.

\begin{tabular}{cccc}
\hline \multirow{2}{*}{$\begin{array}{c}\text { Kelompok yang } \\
\text { Dibandingkan }\end{array}$} & Qhitung & Qtabel & \\
\cline { 3 - 3 } & $\mathbf{\alpha}=\mathbf{0 , 0 5}$ & Kesimpulan \\
\hline A1B1 -- A2B2 & $11,95^{* *}$ & 4,05 & Tolak Ho \\
\hline
\end{tabular}

Berdasarkan hasil perhitungan ANAVA diperoleh hasil Fhitung untuk faktor interaksi yaitu 4,16 lebih besar daripada Ftabel yaitu 3,89 pada taraf nyata $\alpha=0,05$. Sehingga diperoleh hasil Fhitung > Ftabel, maka hipotesis nol (Ho) di tolak dan $\mathrm{H} 1$ diterima. Hasil tersebut menunjukan bahwa terdapat pengaruh interaksi antara penggunaan metode pembelajaran dan kemampuan awal terhadap hasil belajar IPL siswa SMK kelas XI Litrik. Demikian pula uji lanjutan dengan uji tuckey menunjukan bahwa nilai Qhitung = 11,95 yang bernilai lebih besar dari Qtabel $(0,05 ; 4 / 16)=4,05$. Yang berarti bahwa terdapat pengaruh interaksi antara hasil belajar siswa yang memiliki kemampuan awal tinggi dengan menggunakan metode mind mapping dan kemampuan awal rendah dengan menggunakan metode inkuiri.

\section{Hipotesis 5}

Terdapat pengaruh interaksi antara hasil belajar siswa yang memiliki kemampuan awal tinggi dengan menggunakan metode inkuiri (A2B1) dan kemampuan awal rendah dengan menggunakan metode mind mapping (A1B2). Hipotesis secara statistik dapat dirumuskan sebagai berikut:

$$
\begin{aligned}
& \mathrm{H} 0: \text { Int. } \mathrm{A} 2 \mathrm{~B} 1=\text { Int. } \mathrm{A} 1 \mathrm{~B} 2 \\
& \mathrm{H} 1: \text { Int. } \mathrm{A} 2 \mathrm{~B} 1 \neq \text { Int. A1B2 }
\end{aligned}
$$


Tabel 9. Rangkuman Uji Tuckey Pengaruh Interaksi Antara Hasil Belajar Siswa Yang Memiliki Kemampuan Awal Tinggi Dengan Menggunakan Metode Inkuiri Dan Kemampuan Awal Rendah Dengan Menggunakan Metode Mind Mapping.

\begin{tabular}{|c|c|c|c|}
\hline \multirow{2}{*}{$\begin{array}{l}\text { Kelompok yang } \\
\text { Dibandingkan }\end{array}$} & \multirow{2}{*}{$Q_{\text {hitung }}$} & Qtabel & \multirow[b]{2}{*}{ Kesimpulan } \\
\hline & & $\alpha=0,05$ & \\
\hline $\mathrm{A} 1 \mathrm{~B} 2-\mathrm{A} 2 \mathrm{~B} 1$ & $3,74^{\approx \mathrm{ax}}$ & 4,05 & Tolak Ho \\
\hline
\end{tabular}

Berdasarkan hasil perhitungan ANAVA diperoleh hasil Fhitung untuk faktor interaksi yaitu 4,16 lebih besar daripada Ftabel yaitu 3,89 pada taraf nyata $\alpha=0,05$. Sehingga diperoleh hasil Fhitung > Ftabel, maka hipotesis nol (Ho) di tolak dan $\mathrm{H} 1$ diterima. Hasil tersebut menunjukan bahwa terdapat pengaruh interaksi antara penggunaan metode pembelajaran dan kemampuan awal terhadap hasil belajar IPL siswa SMK kelas XI Litrik. Pada rerata yang diperolah siswa yang memiliki kemampuan awal tinggi dengan metode inkuiri yaitu 70,85 tidak lebih baik dari metode mind mapping yang memperoleh hasil rerata 76,39, shingga pada uji lanjutan dengan uji tuckey menunjukan bahwa nilai Qhitung $=3,74$ yang bernilai lebih kecil dari Qtabel $(0,05 ; 4 / 16)=4,05$. Yang berarti bahwa tidak terdapat pengaruh interaksi antara hasil belajar siswa yang memiliki kemampuan awal tinggi dengan menggunakan metode inkuiri dan kemampuan awal rendah dengan menggunakan metode mind mapping.

\section{Kesimpulan}

Dari penilitaan diatas diperoleh kesimpulan sebagai berikut: (1) Secara keseluruhan hasil belajar IPL pada kelompok siswa yang belajar dengan metode mind mapping lebih tinggi dari kelompok siswa yang menggunakan metode pembelajaran inkuiri, yaitu Fhitung untuk metode pembelajaran sebesar 61,28, sedangkan Ftabel sebesar 3,89 pada taraf signifikan $\alpha=0,05$. dengan perkataan lain bahwa metode pembelajaran mind mapping ( rata-rata $=80,94$ ) lebih baik dari pada metode pembelajaran inkuiri (rata-rata $=69,33$ ). Temuan dalam penelitian ini dapat disimpulkan bahwa menggunakan metode mind mapping lebih efektif dalam meningkatkan hasil belajar IPL dibandingkan dengan menggunakan metode pembelajaran inkuiri. (2) Hasil belajar siswa dengan kemampuan awal tinggi menggunakan metode mind mapping memperoleh hasil lebih tinggi dibandingkan dengan menggunakan metode inkuiri. Yaitu memperoleh rerata 85,49 untuk kemampuan awal tinggi yang diberikan metode pembelajaran mind mapping dan 70,85 untuk kemampuan awal tinggi yang diberikan metode pembelajaran inkuiri. Dengan perbandingan Uji tuckey yang menunjukan bahwa Qhitung yaitu 9,89 $>$ Qtabel yaitu 4,05 pada taraf nyata $\alpha=0,05$. Dengan kata lain bahwa menggunakan metode mind mapping untuk siswa yang memiliki kemampuan awal tinggi lebih efektif dibandingkan dengan penggunaan metode pembelajaran inkuiri. (3) Hasil belajar siswa dengan kemampuan awal rendah dengan menggunkan mind mapping memperoleh hasil lebih tinggi dibandingkan dengan menggunakan metode inkuiri, yaitu memperoleh rerata 76,39 untuk kemampuan awal rendah yang diberikan metode pembelajaran mind mapping dan 67,80 untuk kemampuan awal rendah yang diberikan metode pembelajaran inkuiri.dengan perbandingan Uji tuckey yang menunjukan bahwa Qhitung yaitu 5,80 > Qtabel yaitu 4,05 pada taraf nyata $\alpha=0,05$ Kelompok siswa yang memiliki kemampuan awal rendah dengan menggunkan metode mind mapping memperoleh hasil belajar lebih tinggi dibandingkan dengan kelompok siswa yang memiliki kemampuan awal rendah dengan menggunakan metode inkuiri. Ini berarti metode mind mapping lebih efektif digunakan untuk siswa berkemampuan awal rendah dibanding kelompok inkuiri. (4) Terdapat interaksi antara hasil belajar siswa yang memiliki kemampuan awal tinggi dengan metode mind mapping dan kemampuan awal rendah dengan menggunakan metode inkuiri. Berdasarkan hasil perhitungan ANAVA diperoleh hasil Fhitung untuk faktor interaksi yaitu 4,16 lebih besar daripada Ftabel yaitu 3,89 pada taraf nyata $\alpha=0,05$. Sehingga diperoleh hasil Fhitung $>$ Ftabel, maka hipotesis nol (Ho) di tolak dan H1 diterima. Demikian pula uji lanjutan dengan uji tuckey menunjukan bahwa nilai Qhitung $=11,95$ yang bernilai lebih besar dari Qtabel $(0,05$; $4 / 16)=4,05$. Yang berarti bahwa terdapat pengaruh interaksi antara hasil belajar siswa 
yang memiliki kemampuan awal tinggi dengan menggunakan metode mind mapping dan kemampuan awal rendah dengan menggunakan metode inkuiri. (5) Hasil belajar IPL pada siswa yang memiliki kemampuan awal tinggi dengan menggunakan metode inkuiri tidak lebih baik dibanding kelompok siswa yang memiliki kemampuan awal rendah dengan menggunakan metode mind mapping. sehingga tidak terdapat interaksi antara hasil belajar siswa yang memiliki kemampuan awal tinggi dengan metode inkuiri dan kemampuan awal rendah deangan menggunakan metode mind mapping. Pada rerata yang diperolah siswa yang memiliki kemampuan awal tinggi dengan metode inkuiri yaitu 70,85 tidak lebih baik dari metode mind mapping yang memperoleh hasil rerata 76,39, shingga pada uji lanjutan dengan uji tuckey menunjukan bahwa nilai Qhitung $=3,74$ yang bernilai lebih kecil dari Qtabel $(0,05 ; 4 / 16)=$ 4,05.Yang berarti bahwa tidak terdapat pengaruh interaksi antara hasil belajar siswa yang memiliki kemampuan awal tinggi dengan menggunakan metode inkuiri dan kemampuan awal rendah dengan menggunakan metode mind mapping.

\section{DAFTAR PUSTAKA}

Alamin, Mohamad. (2012). Pengaruh Strategi Pembelajaran dan Kemampuan Awal Terhadap Hasil Belajar Biologi di SMP Kota Ternate. [Tesis] Jakarta: Program Pasca Sarjana Universitas Negeri Jakarta.

Arikunto, Suharsimi. (2015). Dasar-dasar EvaluasiPendidikan. Jakarta: Bumi Aksara.

Aziz, Benni. (2012). Pengaruh Metode Pembelajaran Peta Pikiran Terhadap Hasil belajar Siswa pada Materi Pokok Getaran dan Gelombang di Kelas VIII SMP Negeri 12 Binjai. [Jurnal] Medan: Universitas Negeri Medan.

Badri, Sutrisno. (2012). Metode Statistika Untuk Penelitian Kuantitatif. Yogyakarta: Ombak.

Hanun, Farida. (2008). Pengaruh Metode Pembelajaran dan Kemampuan Awal Terhadap Hasil Belajar Matematika. [Jurnal] Jakarta: Puslitbang Pendidikan Agama dan Keagamaan Badan Litbang dan Diklat Depertemen Agama.
Harlanis, Vina. (2018). Pengaruh Model Pembelajaran dan Kemamndirian Belajar Terhadap Kemampuan Berfikir Kritis IPA di SDN Ketileng 2 Cilegon. [Tesis] Jakarta: Program Pasca Sarjana Universitas Negeri Jakarta.

Lefudin. (2017). Belajar dan Pembelajaran Dilengkapi dengan Model

Pembelajaran, Strategi

Pembelajaran, Pendekatan

Pembelajaran, dan Metode

Pembelejaran.Yogyakarta:

Deepublish.

Musfiqon. (2012). Pengembangan Media dan Sumber Pembelajaran. Jakarta: PT Prestasi Pustakaraya.

Nuripah, Enung. (2011). Pengaruh Penggunaan Model Pembelajaran dan Kemampuan Awal Terhadap Hasil Belajar Matematika Siswa SMA. [Tesis] Jakarta: Program Pasca Sarjana Universitas Negeri Jakarta

Purwanto. (2011). Evaluasi Hasil Belajar. Yogyakarta: Pustaka Pelajar. Ratnawulan,Elis., dan Rusdiana. (2015). Evaluasi Pembelajaran. Bandung: CV Pustaka Setia. Riadi, Edi. (2015). Metode Statistika Parametrik \&

Nonparametrik. Tangerang: PT Pustaka Kuantitatif Kualitatif dan $R \& D$. Bandung: CV Alfabeta. Supranto. (2009). Statistik: Teori dan Aplikasi Edisi Ketujuh. Jakarta: Penerbit Erlangga. Mandiri.

Rusman. (2017). Belajar dan Pembelajaran Berorientasi Standar Proses Pendidikan. Depok: PT Kharisma Putra Utama.

Sugiyono. (2015). Metode Penelitian

Susetyo, Budi. (2009). Statistika. Jakarta: Direktorat Jenderal Pendidilan Islam.

Sutikno, Sobry. (2014). Metode \& Model-model Pembelajaran. Lombok: Holistica.

Swadarma, Doni. (2013). Mind Mapping dalam Kurikulum Pembelajaran. Jakarta: PT Elex Media Komputind 